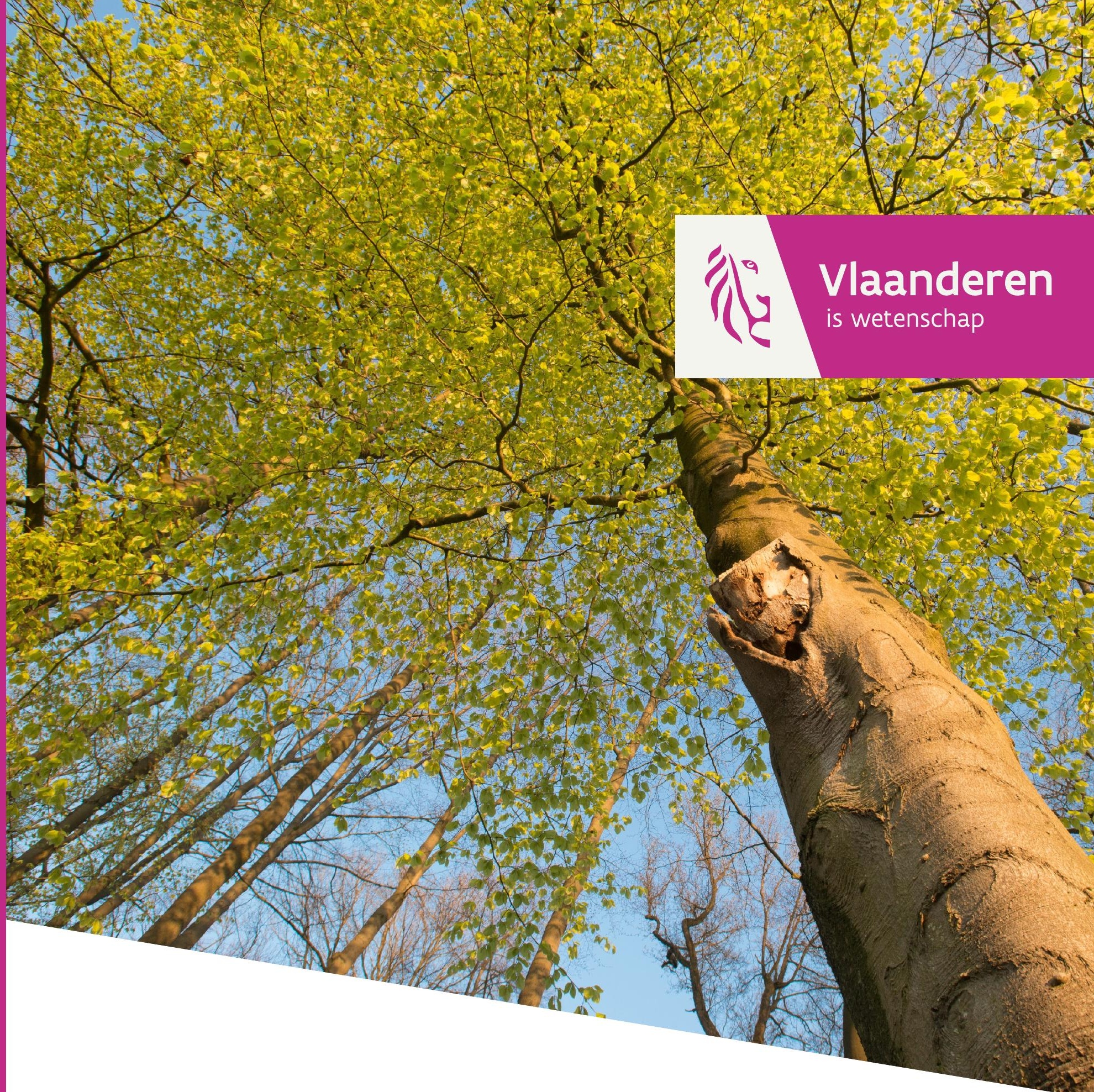

\title{
Handleiding package diameter-hoogtecurves (dhcurve)
}

Els Lommelen en Thierry Onkelinx

INSTITUUT

NATUUR- EN BOSONDERZOEK 
Auteurs:

Els Lommelen en Thierry Onkelinx

Instituut voor Natuur- en Bosonderzoek

Het Instituut voor Natuur- en Bosonderzoek (INBO) is het Vlaams onderzoeks- en kenniscentrum voor natuur en het duurzame beheer en gebruik ervan. Het INBO verricht onderzoek en levert kennis aan al wie het beleid voorbereidt, uitvoert of erin geïnteresseerd is.

\author{
Vestiging: \\ INBO Brussel \\ Herman Teirlinckgebouw \\ Havenlaan 88 bus 73 \\ 1000 Brussel \\ www.inbo.be \\ e-mail: \\ els.lommelen@inbo.be
}

\title{
Wijze van citeren:
}

Lommelen, E. en Onkelinx, T. (2018). Handleiding package diameter-hoogtecurves (dhcurve). Rapporten van het Instituut voor Natuur- en Bosonderzoek 2018 (66). Instituut voor Natuur- en Bosonderzoek, Brussel. DOI: doi.org/10.21436/inbor.14735637

\section{D/2018/3241/186}

Rapporten van het Instituut voor Natuur- en Bosonderzoek 2018 (66)

ISSN: 1782-9054

\section{Verantwoordelijke uitgever:}

Maurice Hoffmann

Foto cover:

De hoogte van een beuk meten in een bos is niet eenvoudig. (C) L. Soerink / Vildaphoto 
INSTITUUT

NATUUR- EN

BOSONDERZOEK

\section{HANDLEIDING PACKAGE DIAMETER-HOOGTECURVES}

\section{(DHCURVE)}

Els Lommelen en Thierry Onkelinx

Rapporten van het Instituut voor Natuur- en Bosonderzoek 2018 (66)

ANB besteknummer: ANB/BPM/2015/DH1 


\section{Inhoudsopgave}

Inhoudsopgave ............................... 1

1 Inleiding ........................... 2

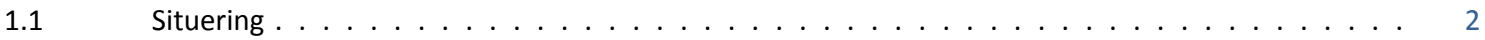

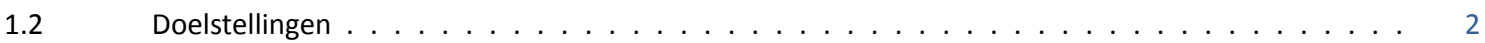

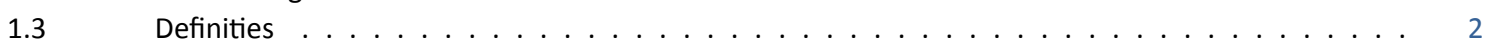

2 Praktische werkwijze ........................ . . . 4

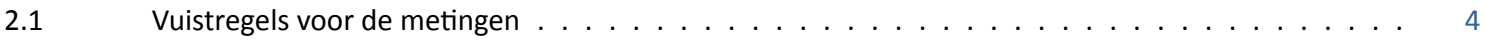

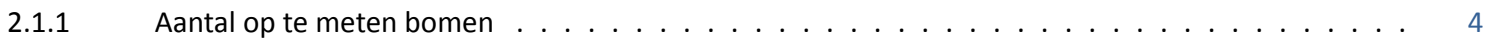

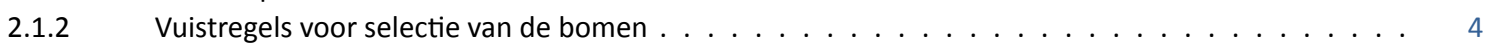

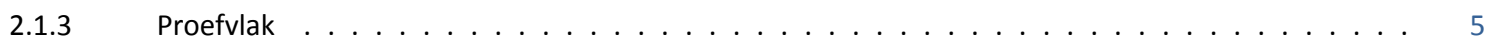

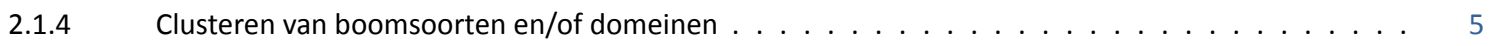

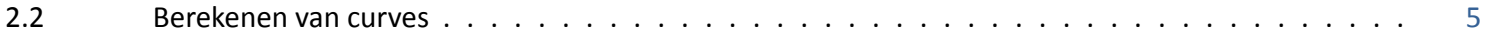

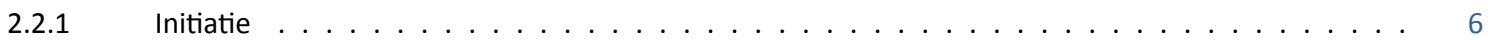

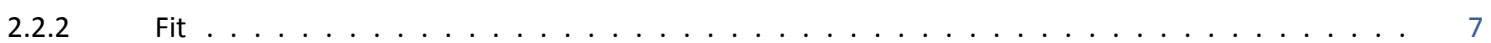

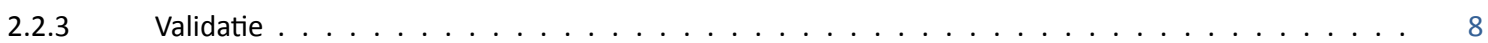

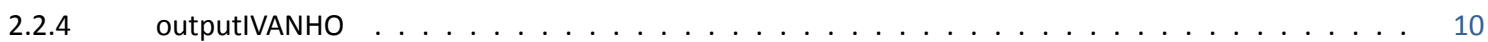

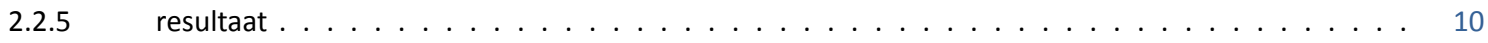

3 Standaardstramien voor berekeningen . . . . . . . . . . . . . . . . . 12

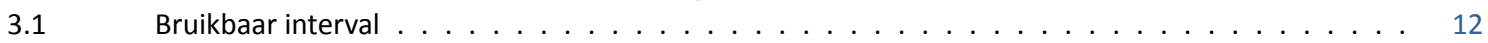

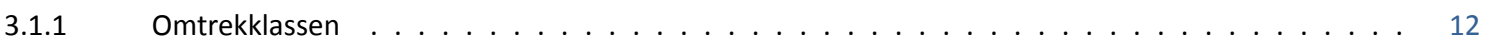

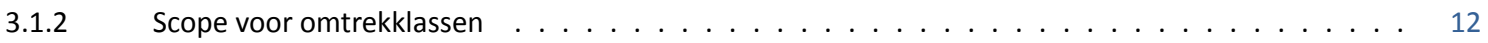

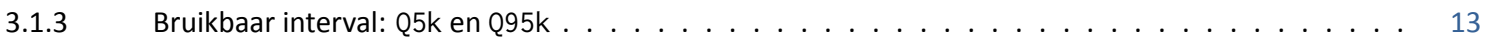

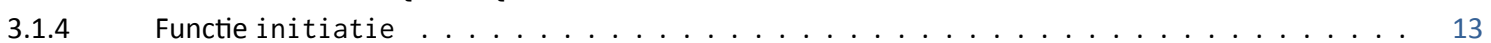

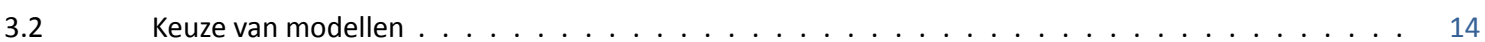

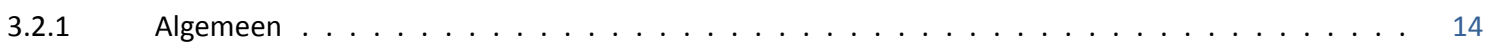

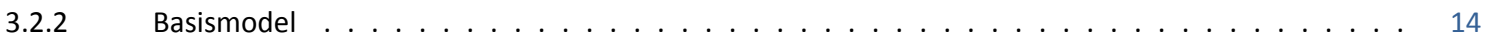

3.2.3 Afgeleid model $\ldots \ldots \ldots \ldots \ldots \ldots \ldots \ldots \ldots$

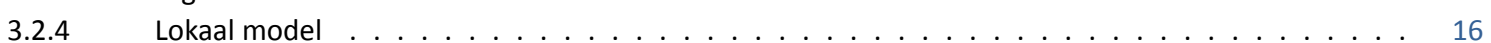

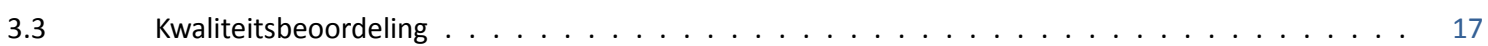

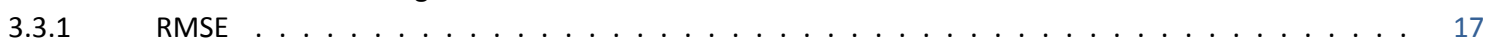

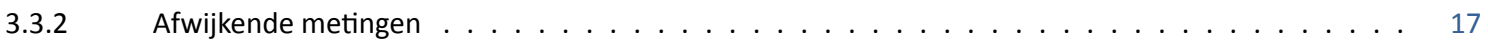

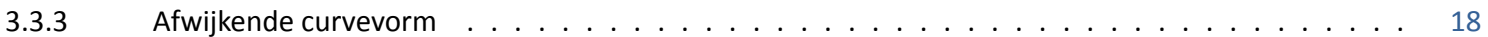

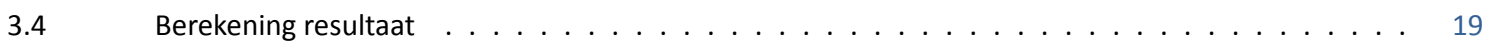

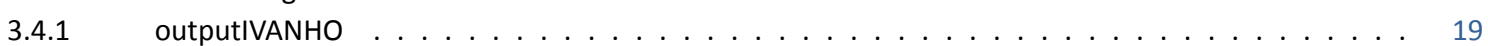

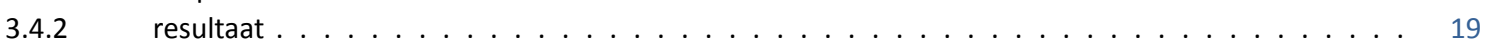




\section{INLEIDING}

\section{1 ȘITUUẸIN!̣}

Een aanbeveling uit het KOBE-project 'Meting na hamering' uit 2012 was om het opmeten van boomhoogtes te vervangen door diameter-hoogtecurves opgesteld aan de hand van bestaande meetgegevens. Hiermee zou bij de volumeschatting van bomen een tijdswinst gerealiseerd kunnen worden zonder substantieel in te boeten aan nauwkeurigheid. Om deze aanbeveling in de praktijk te brengen, is in 2016-2017 het package dhcurve ontwikkeld.

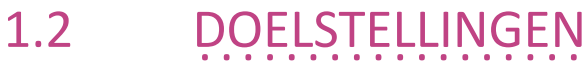

Het package dhcurve bundelt een aantal functies die toelaten om 'diameter-hoogtecurves' op te stellen op basis van bestaande meetgegevens van bomen (omtrek en hoogte). Het eindresultaat is een dataset waarin per boomsoort, domein en omtrekklasse een geschatte hoogte wordt opgegeven, of een dataset met per boomsoort-domein-combinatie de parameters A, B en C van de curve Hoogte $=A+B \log ($ Omtrek $)+$ $C \log (\text { Omtrek })^{2}$.

Het model dat gebruikt wordt om een curve op te stellen en/of de hoogteschattingen te maken, is afhankelijk van het aantal beschikbare metingen (zie definities). Om een betrouwbaar eindresultaat te bekomen, zijn de keuze van de op te meten bomen en de validatie van de gegevens belangrijk (zie Praktische werkwijze). Achtergrondinformatie over de in het package uitgewerkte berekeningswijze is opgenomen onder Standaardstramien voor berekeningen.

\subsection{DEFIN!I!!!ES}

Basismodel: Het meest uitgebreide en nauwkeurige model voor een boomsoort, bestaande uit een overkoepelend deel (= Vlaams model) en een domeinspecifiek deel dat corrigeert voor de standplaats. Dit model wordt berekend voor boomsoorten waarvoor meer dan 50 metingen beschikbaar zijn in minimum 6 domeinen (en enkel voor de domeinen waarvoor minimum 50 metingen beschikbaar zijn).

Vlaams model: Het overkoepelend deel van het basismodel, dus een 'gemiddeld model' op Vlaamse schaal voor een specifieke boomsoort. Zonder correctie voor de standplaats (domein) geeft dit model een minder accurate schatting.

Afgeleid model: Domeinspecifiek model waarbij het Vlaams model gecorrigeerd wordt voor de standplaats door de curve in hoogte te verschuiven, terwijl de curvevorm van het Vlaams model behouden wordt. Dit model wordt berekend voor domeinen waar 10 tot 50 metingen beschikbaar zijn op voorwaarde dat er een basismodel berekend is voor de boomsoort. 
Lokaal model: Domeinspecifiek model waarbij een eigen curve berekend wordt voor elke boomsoortdomeincombinatie waarvoor minimum 50 metingen beschikbaar zijn. Dit model is een alternatief van het basismodel voor boomsoorten waarvan er minder dan 6 domeinen zijn met 50 metingen. In tegenstelling tot het basismodel heeft het lokaal model geen soortspecifiek overkoepelend deel, waardoor er geen Vlaams model kan afgeleid worden. Dit betekent dat er voor boomsoorten waarvoor dit model opgesteld wordt, geen afgeleide modellen berekend kunnen worden voor domeinen met minder dan 50 metingen.

Domeinmodel: Algemene term voor een model dat specifiek op maat van een boomsoort-domeincombinatie berekend is. Het kan hier gaan over een basismodel inclusief domeinspecifiek deel, een afgeleid model of een lokaal model. Deze term moet vooral gezien worden als een tegenstelling van het Vlaams model, dat een gemiddelde is van alle domeinen voor een boomsoort.

Bruikbaar interval: Interval waarbinnen het model in kwestie gebruikt kan worden. Dit interval is afhankelijk van de beschikbare gegevens en van het vooraf vastgelegde relevante bereik (zie Standaardstramien voor berekeningen).

RMSE: De Root Mean Square Error is een waarde in meter die aangeeft hoe groot de spreiding van de metingen is t.o.v. het model en waar in feite ook uit afgeleid kan worden hoe goed het model de metingen benadert. Gelijkaardig aan de standaard error kan een betrouwbaarheidsinterval berekend worden voor de geschatte hoogten (op basis van het model) door 2 maal de waarde van de RMSE op te tellen en af te trekken van de geschatte hoogte. 


\section{PRAKTISCHE WERKWIJZE}

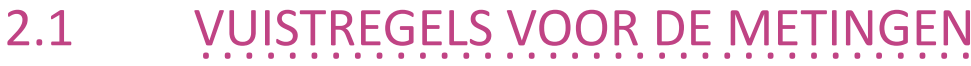

\subsubsection{Aantal op te meten bomen}

Het basismodel, dat het meest uitgebreide modeltype is, heeft enkele voordelen ten opzichte van de andere modeltypen:

- het basismodel wordt op het niveau van een boomsoort opgesteld, waardoor de domeinmodellen deels mee profiteren van de metingen van de boomsoort in andere domeinen (het globale soortmodel 'corrigeert' de domeinmodellen waar nodig, bv. bij omtrekklassen waar weinig metingen beschikbaar zijn).

- het basismodel laat toe om afgeleide modellen te berekenen voor domeinen waarvoor minder metingen van de boomsoort beschikbaar zijn.

Vanwege deze voordelen wordt aangeraden om (voor relevante boomsoorten en domeinen) te streven naar voldoende metingen om dit modeltype te kunnen opstellen, zijnde:

- per domein en boomsoort minstens 50 bomen opmeten verdeeld over de aanwezige omtrekklassen tussen 0,5 en 2,3 m, maar ook kleinere omtrekken opmeten

- minstens 6 domeinen met voldoende metingen

Zolang deze streefcijfers niet gehaald worden, moeten we terugvallen op de andere modeltypen. Omdat deze gebaseerd zijn op minder metingen, hebben deze een breder betrouwbaarheidsinterval (af te leiden van een hoger cijfer voor de RMSE), wat betekent dat de schatting minder precies is.

\subsubsection{Vuistregels voor selectie van de bomen}

Voor een betrouwbaar resultaat is het belangrijk dat de groep gemeten bomen representatief is voor alle bomen van die boomsoort en omtrekklasse die in dat domein staan, wat inhoudt dat ze willekeurig gekozen moeten worden. De geselecteerde bomen moeten in de mate van het mogelijke evenredig gespreid zijn over:

- de beschikbare omtrekklassen

- dominante en onderstandige bomen

- de verschillende leeftijdsklassen

- de bestanden binnen het domein die voor minimum de helft bestaan uit de boomsoort in kwestie, met een voorkeur voor homogene bestanden

De laatste voorwaarde houdt dus enerzijds in dat de voorkeur wordt gegeven aan metingen in homogene bestanden, omdat het bij een houtverkoop belangrijk is dat het volume van de dominant voorkomende boomsoort juist geschat is. Voor de sporadisch voorkomende bomen van een andere soort in dit bestand is een precieze schatting minder belangrijk, dus hiervoor volstaan schattingen op basis van metingen in een homogeen bestand van deze soort. 
Anderzijds houdt deze voorwaarde in dat de geselecteerde bomen van de boomsoort in kwestie evenredig gespreid moeten zijn over de relevante bestanden (dus de bestanden die homogeen zijn voor deze boomsoort of die minimum voor de helft bestaan uit deze boomsoort).

\subsubsection{Proefvlak}

De modellen worden berekend op basis van metingen op domeinniveau, dus puur technisch worden er geen vereisten opgelegd in verband met de verdeling van de bomen over de bestanden of het gebruik van proefvlakken of steekproefcirkels.

Om bovenstande vuistregels te volgen en een subjectieve keuze van de te meten bomen te vermijden, kan het gebruik van een proefvlak echter een voordeel zijn. Nadeel is dat het meer tijd vraagt, en dat het moeilijker is om van alle omtrekklassen voldoende metingen te hebben. Er zou ook gedacht kunnen worden aan een alternatief voor een proefvlak, bijvoorbeeld een rechte lijn door het bos waarlangs alle bomen opgemeten worden.

\subsubsection{Clusteren van boomsoorten en/of domeinen}

Kunnen boomsoorten als ruwe en zachte berk of zomer- en wintereik samengevoegd worden tot berk of inlandse eik? Technisch is dit geen probleem: na het inladen van de gegevens uit de databank en voor het uitvoeren van de analysestappen uit het dhcurve-package kan extra code geschreven worden om deze soorten dezelfde naam en ID-nummer te geven, waardoor ze bij de analyse automatisch als dezelfde soort beschouwd worden. De beslissing welke soorten mogen samengevoegd worden omdat ze dezelfde groeivorm hebben, vereist echter een goede kennis van de boomsoorten. (Eventueel zou voor deze beslissing bijkomend gekeken kunnen worden naar beschikbare metingen en/of modellen van de samen te voegen soorten.) Daarnaast kan - met kennis van zaken - het model van de ene boomsoort gebruikt worden voor een andere soort waarvoor te weinig gegevens beschikbaar zijn. Kortom, dit zijn eerder inhoudelijke keuzes die geen impact hebben op de werking van dhcurve.

Wat als een domein te weinig metingen heeft en een naburig gelijkaardig domein wel een goed model heeft? Kan dat model dan gebruikt worden om voorspellingen te doen voor het andere domein? Initieel was de opzet van het project om 'gelijkaardige' domeinen te clusteren op een zodanige manier dat per cluster eenzelfde model kon gebruikt worden. Maar bij de verkennende studie (uitwerken standaardstramien) bleek dat er geen clustering van domeinen mogelijk was op basis van ecoregio, bodemtype, provincie ( beheermethode), noch vonden we ruimtelijke patronen op basis van de ligging binnen Vlaanderen die tot enige clustering zou kunnen leiden (zie Standaardstramien voor berekeningen/Keuze van modellen/Afgeleid model). Dus op een systematische wijze domeinen samenvoegen op basis van bovenstaande variabelen om eenzelfde model te kunnen gebruiken, lukt niet. Maar met voldoende voorkennis over bepaalde dichtbij elkaar gelegen bosdomeinen en eventueel een vergelijking van beschikbare metingen/modellen (bv. van andere soorten van dezelfde domeinen) kan het misschien voor bepaalde domeinen te verantwoorden zijn om dezelfde modellen te gebruiken? Zo zijn de curves van Heverleebos en Meerdaalwoud zeer gelijkaardig, maar in Bertembos blijkt de hoogte bij dezelfde omtrekklasse lager te zijn.

Technisch kan - net zoals bij de boomsoorten - ook voor domeinen gespeeld worden met het samenvoegen of opsplitsen van domeinen: zodra gegevens eenzelfde domeinID hebben, worden ze bij de berekeningen als behorend tot eenzelfde domein beschouwd. Dit biedt dus ook de mogelijkheid om afwijkende bestanden in eenzelfde domein te beschouwen als afzonderlijke domeinen. 
De zogenaamde diameter-hoogte-curves, die in feite omtrek-hoogte-curves zijn, kunnen berekend worden door het hieronder weergegeven voorbeeldscript te runnen voor een opgegeven dataset Data (zie initiatie). Hierbij is het de bedoeling dat bij elke validatiestap een validatie gebeurt, waarna het script met de gevalideerde data opnieuw gerund wordt (zie validatie).

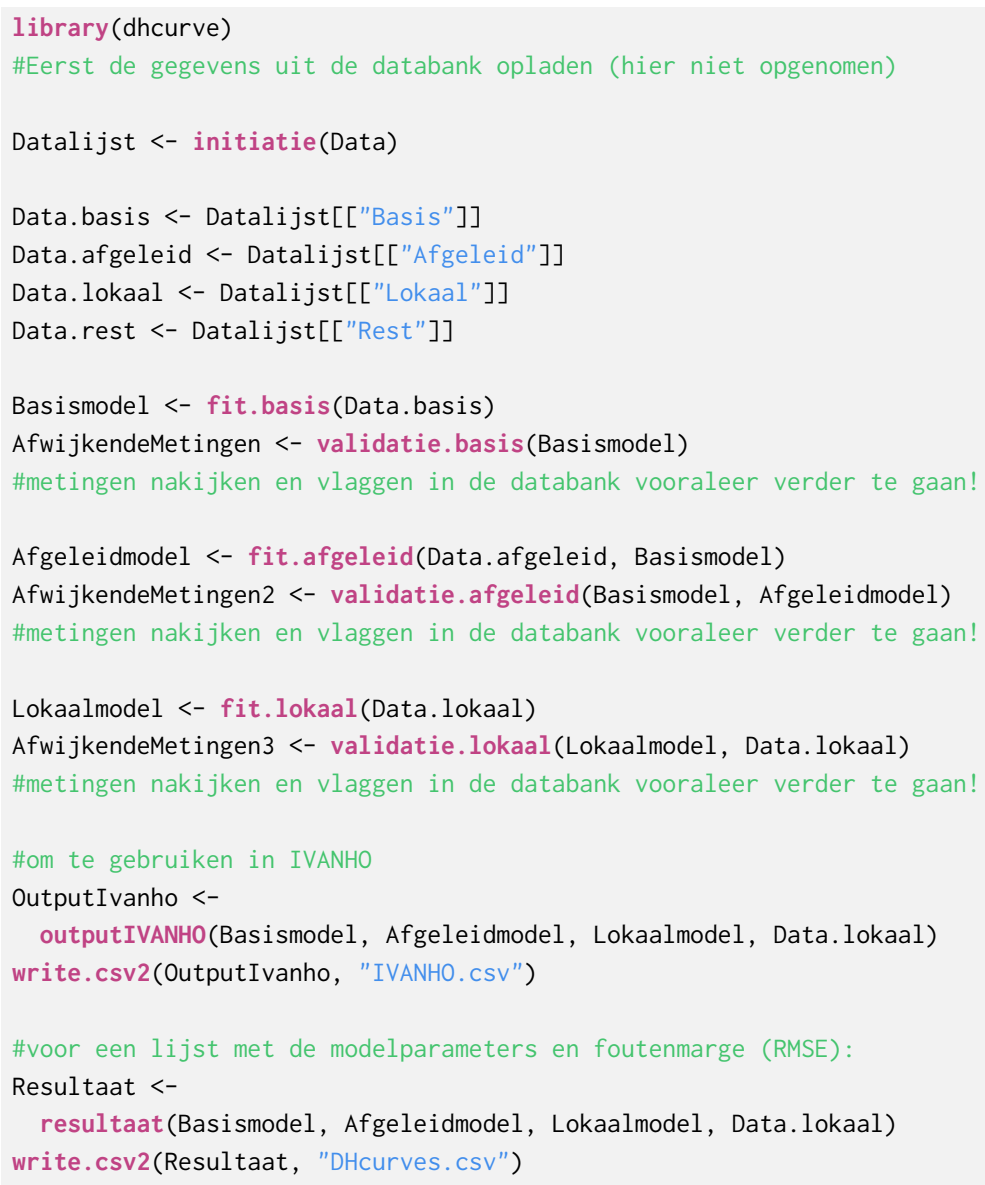

De stappen 'fit' en 'validatie' worden achtereenvolgens doorlopen voor de verschillende modeltypen (basismodel, afgeleid model en lokaal model). Deze stappen (inclusief de initiatiestap en de finale stappen) worden hieronder kort toegelicht vanuit praktisch oogpunt, met focus op de workflow en aandachtspunten. Voor meer informatie over het gebruik van de functies (om ze bv. buiten deze standaard workflow te gebruiken) verwijzen we naar de helpfunctie van de functie in kwestie (in $\mathrm{R}$ aan te roepen door $?<$ functienaam $>$ ), voor achtergrondinformatie over de achterliggende berekeningen verwijzen we naar het laatste deel van dit document: Standaardstramien voor berekeningen.

\subsubsection{Initiatie}

De curves worden berekend op basis van een dataframe Data met metingen van bomen, die de volgende informatie moet bevatten:

- DOMEIN_ID: het identificatienummer van het domein

- BOS_BHI: de naam van het domein

- IDbms: het identificatienummer van de boomsoort

- BMS: de naam van de boomsoort 
- C13: de omtrek van de boom in cm (gemeten op $130 \mathrm{~cm}$ hoogte)

- HOOGTE: de hoogte van de boom in meter

- Status: in hoeverre er foutcontrole op de meting gedaan is, mogelijke categorieën: 'Niet gecontroleerd', 'Te controleren', 'Goedgekeurd', 'Afgekeurd', 'Negeren', 'Aangepast',...

Bedoeling is dat gegevens met status anders dan 'Niet gecontroleerd', 'Te controleren' of 'Goedgekeurd' voor het uitvoeren van deze initiatiestap uit de dataset verwijderd worden.

Bij de initiatiestap wordt op basis van de omtrek C13 (in te voeren in cm!) een omtrekklasse berekend met eenheid in meter en alle verdere rekenstappen gebeuren in meter.

De hier berekende omtrekklassen komen overeen met deze in IVANHO ${ }^{1}$ (gemeten op 1,3 m hoogte): ze gaan omhoog met stappen van 0,1 $\mathrm{m}(10 \mathrm{~cm})$, bv. de klasse van 0,35 $\mathrm{m}$ bevat de bomen met omtrek tussen 0,3 en 0,4 m. Het klassemidden van de omtrekklasse (in het voorbeeld 0,35 m) wordt opgeslagen in de variabele Omtrek, in een finale fase wordt uit deze variabele het interval van de klassegrenzen afgeleid.

De verdere analysen gebeuren voornamelijk op basis van bomen met omtrek tussen 0,5 en 2,3 m, wat betekent dat de gegevens van zeer dunne en zeer dikke bomen niet gebruikt worden (zie Standaardstramien voor berekeningen voor meer achtergrondinformatie over deze keuze). Daarom worden bomen met omtrek kleiner dan 0,2 $\mathrm{m}$ en bomen met omtrek groter dan 2,4 $\mathrm{m}$ al tijdens deze initiatiestap uit de dataset verwijderd. Om enige controle te hebben over wat verwijderd wordt en eventuele fouten te kunnen rechtzetten, genereert de functie ini tiatie een overzichtsrapport met instructies hoe de grootste problemen gemakkelijk opgespoord kunnen worden. (Een potentiële fout hier is het gebruik van een verkeerde eenheid voor de metingen, en het ten onrechte verwijderen van een boom kan gevolgen hebben voor het al dan niet kunnen fitten van een bepaald modeltype.)

Behalve Omtrek berekent de functie initiatie nog enkele andere variabelen die nodig zijn voor de analysestappen. Daarna wordt de dataset opgesplitst in 4 delen in functie van de modeltypen waarvoor de gegevens gebruikt kunnen worden (waarbij de gegevens van elke boomsoort-domeincombinatie worden toegevoegd aan het meest ambitieuze modeltype dat haalbaar is):

- Basismodel (boomsoorten met > 50 metingen per domein in de omtrekklassen tussen 0,5 en 2,3 m en $>=6$ domeinen)

- Afgeleid model (domeinen met 10-50 metingen in de omtrekklassen tussen 0,5 en 2,3 m voor boomsoorten waarvoor basismodel opgesteld is)

- Lokaal model (boomsoorten met > 50 metingen per domein in de omtrekklassen tussen 0,5 en 2,3 m en $<6$ domeinen)

- Rest (alle overblijvende gegevens, dus gegevens die niet gebruikt kunnen worden om een model te fitten)

De functie geeft een list terug met deze 4 datasets als items met namen 'Basis', 'Afgeleid', 'Lokaal' en 'Rest'. De 3 eerstgenoemde datasets kunnen gebruikt worden om de verschillende modeltypen te berekenen.

\subsubsection{Fit}

Voor elk van de drie hierboven geselecteerde datasets wordt een gepast model berekend of 'gefit' op basis van een voor dat modeltype specifieke functie. De output is voor elk modeltype verschillend; de functies waarbij deze modeltypen als parameter meegegeven moeten worden, zijn aangepast om met deze verschillen om te gaan (of zijn ook modelspecifiek).

\footnotetext{
${ }^{1}$ ANB databank met metingen voor houtverkoop
} 
Een aandachtspunt is dat het berekende basismodel (in feite het hieruit af te leiden Vlaams model) nodig is om het afgeleid model te kunnen berekenen; het lokaal model is onafhankelijk van deze en kan dus afzonderlijk berekend worden.

Als een lege dataset als parameter meegegeven wordt, zal de functie fit.xxx een foutmelding geven. Als de reden voor deze lege dataset onduidelijk is, is het aan te raden om het overzichtsrapport gegenereerd door de functie initiatie te bekijken. Om de berekeningen enkel te doen voor de andere modeltypen (waarvan de dataset niet leeg is), moet het hierboven weergegeven script aangepast worden door alles wat met deze functie te maken heeft, te verwijderen: het blokje script met fit.xxx en validatie.xxx, en onderaan de desbetreffende parameter(s) in de functies output IVANHO en/of resultaat.

\subsubsection{Validatie}

Idee van de validatiestap is om aan foutcontrole te doen, waar nodig de gegevens in de databank aan te passen, de analyse te herhalen met de aangepaste gegevens en deze cyclus voor de basismodellen te herhalen 'tot alles in orde is'. Daarna kan verder gegaan worden met de analyse van het afgeleide modellen, waar bij de validatie weer dezelfde cyclische procedure doorlopen wordt. Vermits nu de basismodellen in orde zijn, mag hier de (tijdrovende) validatiestap overgeslagen worden. Deze functie moet dus niet meer opnieuw gerund worden zolang er geen aanpassingen zijn in de hiervoor gebruikte gegevens in de dataset. $\mathrm{Na}$ de validatie van de afgeleidde modellen, is het de beurt aan de lokale modellen.

De validatie gebeurt op basis van een validatierapport dat de functie validatie. xxx genereert, waarin de modellen (curves) en de meetresultaten (stippen) grafisch weergegeven zijn, met potentiële afwijkingen in rood. Enkel grafieken met potentiële afwijkingen worden in het rapport opgenomen, wat betekent dat het aantal te controleren grafieken vermindert naargelang er meer problemen opgelost worden. Idealiter stopt de validatiestap dus met een leeg validatierapport, in elk geval stopt de validatiestap pas zodra de validator geoordeeld heeft dat geen van de potentiële afwijkingen (in rood) in het validatierapport effectief een probleem vormen.

Belangrijk is dat de validatie in 2 stappen gebeurt, waarbij de tweede stap pas uitgevoerd mag worden van zodra de eerste stap volledig in orde is. Als in de tweede stap aanpassingen gebeuren, moet bij de volgende cyclus ook de eerste stap opnieuw bekeken worden. (Door aanpassingen in de databank verandert telkens het model en ook de afwijkende metingen, die op basis van het model berekend worden.)

\subsubsection{Stap 1: afwijkende metingen}

Bedoeling hier is dat de meest afwijkende meetresultaten gecontroleerd worden op juistheid en uiteindelijk in de databank de status 'Goedgekeurd', 'Afgekeurd', 'Negeren', 'Aangepast',... krijgen. Deze te controleren afwijkingen worden weergegeven als rode stippen in de grafieken in het validatierapport. (Het gaat hier over de meetresultaten die het meest afwijken van de modelcurve met uitzondering van de meetresultaten die al de status 'Goedgekeurd' hebben.)

De functie validatie.xxx geeft de afwijkende metingen ook als dataframe terug, wat toelaat om de status van de betreffende meetresultaten (die in principe op 'Niet gecontroleerd' staan) in de databank scriptmatig aan te passen naar 'Te controleren'. Een voorbeeld (enkel uitgewerkt voor 'Bosdat'-gegevens):

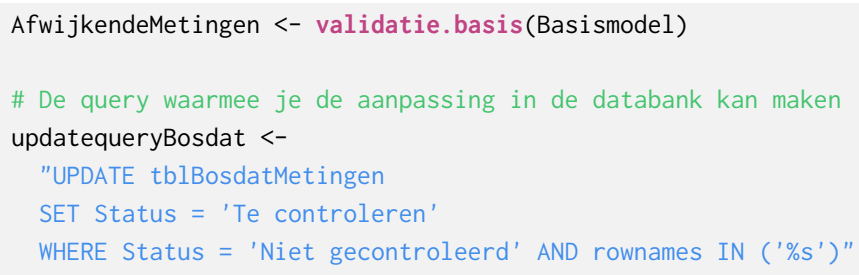




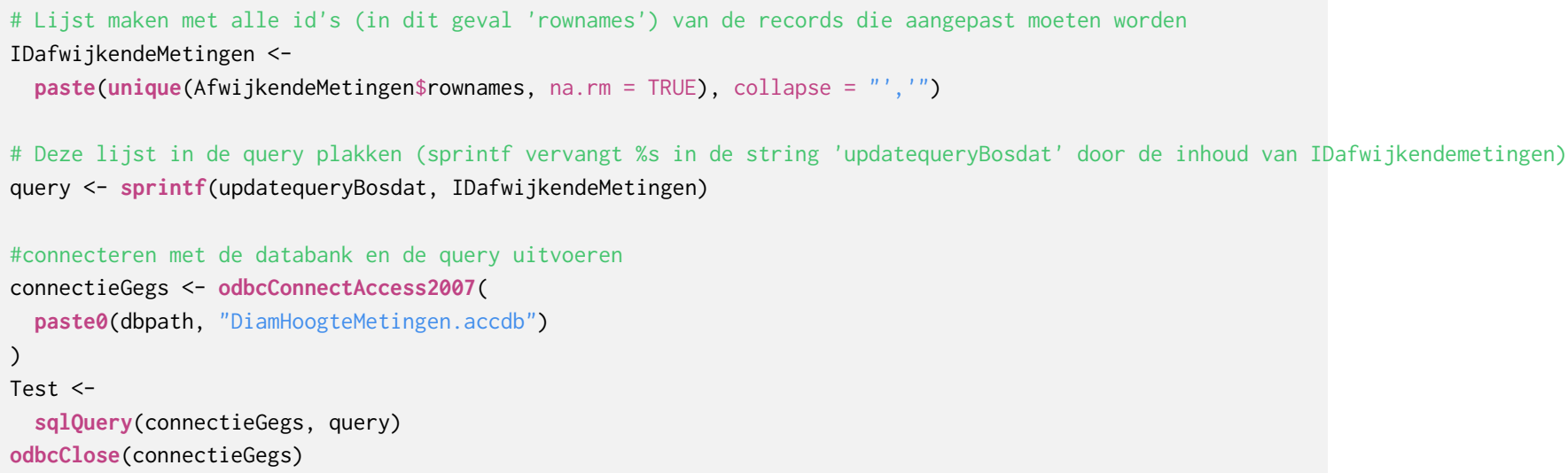

Na het 'verwijderen' (= als afgekeurd of negeren labelen) of aanpassen van gegevens is het belangrijk om de gegevens opnieuw in te laden en het model opnieuw te berekenen. Dit zal immers wijzigen, waardoor er mogelijk andere metingen als afwijkend aangeduid zullen worden.

Meermaals alle afwijkende metingen verwijderen zal tot gevolg hebben dat de foutenmarge smaller wordt (waardoor er telkens nieuwe afwijkende metingen aangeduid worden) en dat uiteindelijk enkel bomen met 'ideale verhoudingen' overblijven. Op dat moment zal het model geen reflectie meer zijn van een realistische situatie, omdat de natuurlijke variatie ontbreekt. In het slechtste geval worden afwijkende metingen verwijderd tot er niet meer genoeg gegevens overblijven om het gekozen modeltype te fitten. Het is dus geen goed idee om systematisch alle afwijkende metingen te verwijderen.

Het goedkeuren van afwijkende metingen zal sneller tot een stabiel model leiden (niets verwijderen verandert het model niet), al is het uiteraard wel de bedoeling dat foute of onbetrouwbare metingen verwijderd worden. Deze beïnvloeden immers het model in negatieve zin, zeker als ze sterk afwijken van de andere meetresultaten en/of in de hoogste of laagste omtrekklassen voorkomen.

Je mag pas verdergaan naar stap 2 als alle rode stippen uit het validatierapport verdwenen zijn.

\subsubsection{Stap 2: afwijkende curves}

Deze stap moet enkel gebeuren bij het basismodel en het lokaal model, niet bij het afgeleid model. (Dit omdat de curvevorm van het afgeleid overgenomen wordt van het basismodel en bijgevolg daar al gecontroleerd is.)

Bedoeling van deze tweede stap is om aan de hand van de curvevorm na te gaan of het model geen te sterke afwijkingen vertoont en dus bruikbaar is als model. Mogelijk afwijkende delen in de curves zijn in rood getekend.

\section{Welke problemen kunnen optreden en hoe beoordelen?}

- 'curvevorm hol bij lage omtrekklassen': dit is waarschijnlijk geen probleem als het rood gekleurde deel maar 1-2 omtrekklassen omvat of als de curve min of meer recht is. Wel problematisch zijn een U-vormige curve, een curve in de vorm van hockeystick of een S-vormige curve.

- 'curve daalt terug bij hoge omtrekklassen': dit is geen probleem als het rood gekleurde deel minder dan 5 omtrekklassen omvat, en het is wel een probleem als het gaat over een aanzienlijk deel van de curve. Houd bij de beoordeling in het achterhoofd dat voor de hoogteschattingen voor IVANHO de maximale hoogte van de curve zal gebruikt worden voor de (rood gekleurde) hogere omtrekklassen. De 'curve' zal hier met andere woorden niet dalen maar horizontaal lopen. 
Wat met de probleemcurves? Deze curves zijn niet goed genoeg om te gebruiken als model in IVANHO (of elders), en er moeten bijkomende metingen uitgevoerd worden vooraleer dit model eventueel kan verbeteren. Dus tot deze extra metingen gebeurd zijn, willen we dit model eigenlijk niet gebruiken. Als het gaat over een berekend basismodel, kunnen de gegevens eventueel wel gebruikt worden om een afgeleid model te berekenen voor dit domein.

Praktisch pakken we dit aan door voor die specifieke domein-boomsoortcombinatie het minimum aantal bomen om een basismodel (of lokaal model) te berekenen, op te trekken. We raden aan om als nieuwe grenswaarde 10 bomen meer te nemen dan het huidige aantal bomen (met omtrek groter dan 0,5 m). Redenering: 1 extra gemeten boom zal de curve niet substantieel verbeteren, 10 misschien wel? In de functie initiatie is de mogelijkheid voorzien om als parameter een dataframe mee te geven met de uitzonderingen voor deze minimumwaarde van 50 bomen. Deze laat ook toe om de minimumwaarde voor het afgeleid model (standaard 10 bomen) op te trekken ingeval er problemen zijn met deze curve (bv. meetresultaten te verspreid).

Onderstaand voorbeeld toont hoe de limiet van het aantal bomen voor Zomereik in de Gavers opgetrokken wordt naar 65 bomen (momenteel zijn hier 55 bomen met omtrek groter dan 0,5 m opgemeten en stel dat we de curve niet betrouwbaar genoeg vinden omdat er te weinig bomen opgemeten zijn in de hogere omtrekklassen). De limiet voor het afgeleide model houden we bij 10 bomen (min_afgeleid = NA, dus we kennen hier geen waarde toe).

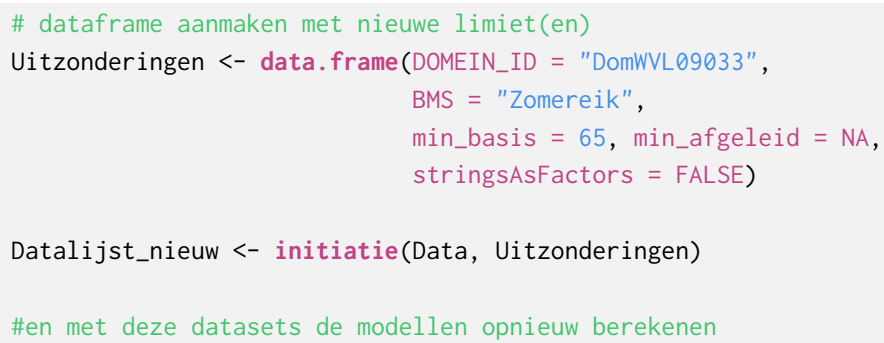

Qua workflow zou het zinvol kunnen zijn om deze uitzonderingen op te slaan in een spreadsheet of databank, eerder dan dit hard te coderen in een script.

Als geen van de afwijkende (rode) curves in het validatierapport een probleem zijn, mag je verdergaan (ondanks het feit dat het validatierapport nog niet leeg is).

OPMERKING Er kunnen ook andere problemen optreden waarop niet expliciet wordt gevalideerd, bijvoorbeeld een slechte verdeling van de bomen over de verschillende omtrekklassen. Bij het basismodel gaat hier de curve sterk aanleunen tegen het Vlaams model, bij het lokaal model gaat hier de curve recht door de weinige aanwezige metingen (die niet per definitie 'gemiddeld' zijn). Ook hier kan beslist worden om het model voorlopig niet te gebruiken (in afwachting van meer metingen) door bovenstaande methode.

\subsection{4 outputIVANHO}

De functie output IVANHO genereert op basis van de berekende (gefitte) modellen een tabel met per boomsoortdomein-combinatie en per diameterklasse een geschatte hoogte, om te gebruiken in IVANHO.

\subsection{5 resultaat}

De functie resul taat genereert op basis van de berekende (gefitte) modellen een tabel met volgende info:

- DomeinID 
- BMS (boomsoort)

- Model type: basismodel / afgeleid model / lokaal model / geen model

- parameters A, B en C per model en per boomsoort

- bruikbaar interval (Q5k en Q95k)

- RMSE

- nBomen: aantal metingen met omtrek $<2,4 \mathrm{~m}$

- nBomenInterval: aantal metingen waarop het model gebaseerd is (ingeval van basismodel of lokaal model)

- nBomenOmtrek05: aantal metingen $>0.5 \mathrm{~m}$ (dus het aantal metingen waarop de RMSE-berekening gebaseerd is en ingeval van een afgeleid model ook het model) 


\section{STANDAARDSTRAMIEN VOOR BEREKENINGEN}

Terwijl het vorige hoofdstuk eerder praktijkgericht was, behandelt dit hoofdstuk de achterliggende berekeningen van de verschillende functies, alsook de redenen waarom voor een bepaalde aanpak of berekeningswijze gekozen is.

Kort gezegd laat dit package toe om de hoogtes van bomen te schatten door middel van een model, dat we opstellen op basis van eerder uitgevoerde metingen per boomsoort-domeincombinatie. Een model is altijd een benadering van werkelijkheid, dat er liefst zo goed mogelijk bij aansluit (cfr. George Box: "All models are wrong, but some are useful"). Belangrijk is dat het model vooral een goede voorspelling geeft binnen de relevante scope. Hoe breder deze scope gedefinieerd wordt, hoe moeilijker het is om een model te vinden dat de werkelijkheid overal goed gaat benaderen en hoe groter de kans dat het model ergens meer afwijkt dan wenselijk. Hoe smaller de scope, hoe nauwkeuriger de voorspelling van het model, maar het model is dan ook enkel bruikbaar binnen deze scope. Om een optimaal model te vinden, komt het er dus op aan om deze scope zo goed mogelijk af te bakenen: niet te smal, maar ook niet te breed. Daarnaast moeten ook voor het model zelf afwegingen en keuzes gemaakt worden, o.a. met betrekking tot complexiteit en betrouwbaarheid. De keuzes die voor de modellen in dit package gemaakt zijn en de achterliggende redenen worden in dit hoofdstuk behandeld.

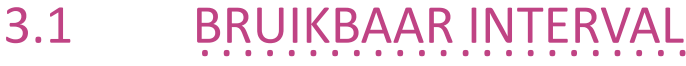

\subsubsection{Omtrekklassen}

De opdrachtgever verwacht als resultaat een hoogteschatting voor elke omtrekklasse (per stap van 0,1 m, bv. de klasse van 0,35 m bevat de omtrekken tussen 0,30 en 0,40 m). Bovendien is voor een deel van de aangeleverde gegevens de omtrek niet exact gemeten, maar weergegeven als omtrekklassen. Om deze redenen is gekozen om het model niet op te stellen op basis van een continue variabele omtrek, maar op basis van een discrete variabele 'omtrekklasse'. Een continue variabele zou eerder een vals gevoel van nauwkeurigheid geven, want de gemeten omtrekken zijn afgerond tot op een bepaalde meeteenheid, dus het zijn sowieso discrete variabelen.

Als de omtrekklassen als categorische variabelen gedefinieerd zouden worden, zou het model louter bestaan uit een geschatte hoogte per omtrekklasse, waarbij het verband tussen omtrek(klasse) en hoogte niet in rekening gebracht kan worden. Het gevolg is dat 'afwijkende' hoogteschattingen binnen een model niet gecorrigeerd zouden worden op basis van hoogteschattingen van andere omtrekklassen. Als de omtrekklassen als discrete variabelen gedefinieerd worden, waar we hier voor gekozen hebben, kan het model wel opgesteld worden als een verband tussen omtrek(klasse) en hoogte.

Het feit dat de omtrekklassen gedefinieerd zijn als een discrete variabele, heeft als belangrijk gevolg dat het model resulteert in een schatting per omtrekklasse en dus niet in een continu verband tussen omtrek en hoogte. Dit is zeer belangrijk om rekening mee te houden bij de interpretatie van de gegevens. 


\subsubsection{Scope voor omtrekklassen}

De opdrachtgever gaf ons het relevante bereik wat betreft de diameter: tussen 15 en $75 \mathrm{~cm} \mathrm{DBH}$, wat overeenkomt met de omtrekklassen tussen 0,5 en 2,3 m. Focus ligt dus op een goede voorspelling binnen dit interval (scope), en de berekening van de foutenmarge (RMSE) gebeurt in elk van de modellen voor dit interval. (Noot: in de praktijk zijn zelden bomen met omtrek groter dan 1,5 tot $2 \mathrm{~m}$ opgemeten, waardoor het maximum van het model vaak lager ligt dat $2,3 \mathrm{~m}$.)

Vermits metingen buiten het relevante interval ook een invloed hebben op de vorm van de curve binnen dat interval (ze 'trekken' aan de hele curve), is het belangrijk om goed de invloed na te gaan van het al dan niet meenemen van deze metingen. Omdat we voor het basismodel en lokaal model gemerkt hebben dat het meenemen van de metingen van de lagere omtrekklassen vaak een betere curvevorm geeft bij de gekozen wiskundige functie, hebben we ervoor gekozen om deze lagere omtrekklassen mee te nemen voor het berekenen van het model. Bij hogere omtrekklassen, die eigenlijk niet zo vaak voorkwamen, zagen we dit voordeel niet. Daarom hebben we bomen met omtrek > 2,4 m altijd weggelaten (voor alle modellen).

Voor het berekenen van het afgeleid model (= verschuiving van het Vlaams model) worden de lagere omtrekklassen niet meegenomen. Bij de berekening van de foutenmarge (RMSE) worden deze omtrekklassen ook niet meegenomen. Hier bekom je immers het meest optimale model voor je scope als je de Vlaamse curve verschuift zodat deze zo dicht mogelijk aansluit bij de metingen van het gekozen interval. $\mathrm{Bij}$ het meenemen van lagere omtrekklassen bepalen deze metingen mee de ligging van de curve, met een (mogelijk) minder goede benadering in het gekozen interval tot gevolg.

\subsubsection{Bruikbaar interval: Q5k en Q95k}

De 'randpunten' van het gebruikte interval (dus de metingen aan het minimum en maximum van het gekozen interval) hebben door de zogenaamde hefboomwerking vaak een zeer grote invloed op het model (de vorm van de curve). Als deze metingen betrouwbaar zijn en in lijn liggen met de andere metingen, 'trekken' ze vaak de curve in de juiste vorm. Anders is als deze metingen potentieel afwijkend zijn, want dan kunnen ze de hele curve in een verkeerde richting trekken, wat uiteraard ongewenst is. Dit probleem kan zich potentieel voordoen als er aan de rand van het interval maar enkele metingen gebeurd zijn, omdat deze toevallig kunnen afwijken van andere metingen. We verwachten dat dit probleem zich niet zal voordoen als de uiterste omtrekklassen veel metingen bevatten, want de kans is zeer klein dat deze allemaal afwijkend zijn (dus we gaan ervan uit dat het gemiddelde van deze grotere groep metingen geen afwijkend cijfer oplevert). We kunnen dit probleem dus vermijden door te zorgen dat de uiterste omtrekklassen nooit bestaan uit weinig metingen, wat eenvoudigweg kan door de grenzen van het gebruikte interval te bepalen op basis van kwantielen: we gebruiken de gegevens tussen het kwantiel van 2,5\% - 1 omtrekklasse (Q5k) en kwantiel van $97,5 \%+1$ omtrekklasse (Q95k), waarbij telkens de volledige omtrekklasse genomen wordt waarin de betreffende waarde valt. We noemen dit interval het bruikbaar interval, en we gebruiken enkel de gegevens binnen dit interval voor het berekenen van de modellen.

Dit is tevens het interval waarin het model voldoende betrouwbare schattingen levert.

\subsubsection{Functie initiatie}

De functie initiatie berekent per boomsoort-domein-combinatie enkele variabelen die verband houden met dit bruikbaar interval:

- bruikbaar interval (Q5k en Q95k) 
- aantal bomen (nBomen), waarbij de bomen met omtrek > 2,4 m buiten beschouwing gelaten worden

- aantal bomen binnen bruikbaar interval (nBomenInterval)

- aantal bomen binnen bruikbaar interval met omtrek >0,5 m (nBomen0mtrek05)

Op basis van het aantal bomen binnen het bruikbaar interval met omtrek $>0,5 \mathrm{~m}$ splitst de functie ini tiatie de dataset op in functie van de verschillende modeltypen (zie initiatie onder praktische werkwijze).

\subsection{KEUZE VAN MOQDELLEN}

\subsubsection{Algemeen}

Voor de keuze van de wiskundige vergelijking die binnen het bruikbaar interval een goede schatting geeft, hebben we 17 modellen uit de literatuur uitgetest. Voor de selecties hebben we ons voornamelijk gebaseerd op de RMSE, die aangeeft hoe goed het model de metingen benadert. Bijkomend hebben we de curvevorm visueel beoordeeld, wat in feite een gelijkaardig resultaat gaf. We zijn in 4 fasen tewerk gegaan:

- alle modellen getest voor de metingen van beuk uit Zoniënwoud en de slechtste modellen geschrapt

- de overblijvende modellen getest op de metingen van beuk van 4 andere domeinen met veel beuken

- de 5 beste modellen (geselecteerd in voorgaande stappen) ook getest voor grove den en zomereik (telkens voor de domeinen met het meeste metingen). Deze modellen zijn:

$$
\begin{gathered}
\text { Hoogte } \sim A+\text { B.Omtrek }+ \text { C.Omtrek }{ }^{2} \\
\text { Hoogte } \sim 1,3+\frac{\text { Omtrek }^{2}}{A+\text { B.Omtrek }+ \text { C.Omtrek }^{2}} \\
\text { Hoogte } \sim e^{\left(A+B \log (\text { Omtrek })+C \log \left(\text { Omtrek }^{2}\right)\right.} \\
\text { Hoogte } \sim A+B \log (\text { Omtrek }) \\
\text { Hoogte } \sim e^{(A+B \log (\text { Omtrek })+\text { C.Omtrek })}
\end{gathered}
$$

- een alternatief model met gelijkaardige karakteristieken dat in de oorspronkelijke lijst ontbrak, op dezelfde manier getest:

$$
\text { Hoogte } \sim A+B \log (\text { Omtrek })+C \log (\text { Omtrek })^{2}
$$

Uiteindelijk hebben we uit deze 6 modellen 2 modellen gekozen die in al de geteste omstandigheden een goede schatting gaven: een exponentieel model (Hoogte $\sim e^{\left(A+B \log (\text { Omtrek })+C \log (\text { Omtrek })^{2}\right)}$ ) en het zelf toegevoegde alternatief. Dit laatste heeft als voordeel dat het een lineair model is, wat een groot voordeel is voor de berekeningen (fitten van model) en de interpretatie van de parameters A, B en C. Vandaar dat we dit model gekozen hebben:

$$
\text { Hoogte } \sim A+B \log (\text { Omtrek })+C \log (\text { Omtrek })^{2}
$$




\subsubsection{Basismodel}

Voor het basismodel starten we van het hierboven voorgestelde algemene model. Om eventuele afwijkingen bij boomsoort-domeincombinaties deels te corrigeren op boomsoortniveau, kiezen we om een mixed model te maken per boomsoort waarin voor elk domein een extra parameter toegevoegd wordt. De notatie hiervan is als volgt:

Hoogte $_{\text {basis }} \sim A_{\text {Vlaams }}+A_{\text {domein }}+\left(B_{\text {Vlaams }}+B_{\text {domein }}\right) \log ($ Omtrek $)+\left(C_{\text {Vlaams }}+C_{\text {domein }}\right) \log (\text { Omtrek })^{2}$

Dit model bevat dus een soortspecifiek overkoepelend model met parameters $A_{\text {Vlaams }}, B_{\text {Vlaams }}$ en $C_{\text {Vlaams }}$ (in vaktermen fixed factor genoemd), wat we definiëren als 'Vlaams model'. Daarnaast bevat het model de domeinspecifieke parameters $A_{\text {domein }}, B_{\text {domein }}$ en $C_{\text {domein }}$ (in vaktermen random factor genoemd), die gesommeerd met de overkoepelende parameters de parameters voor het domeinspecifieke model geven.

Dit overkoepelend Vlaams model wordt berekend op basis van alle gegevens, waarbij domeinen met veel gegevens zwaarder doorwegen op het eindresultaat. De domeinspecifieke modellen worden grotendeels berekend op basis van de gegevens van dat domein, maar er wordt ook gecorrigeerd op basis van het overkoepelende Vlaams model. Hierbij zal de invloed van het Vlaams model zwaarder doorwegen in domeinen en/of specifieke omtrekklassen waar niet veel domeinspecifieke gegevens beschikbaar zijn. Als er voldoende domeinspecifieke gegevens beschikbaar zijn, zal het domeinmodel vooral daarop gebaseerd zijn.

Dit betekent dus dat het Vlaams model de domeinspecifieke modellen corrigeert waar onvoldoende gegevens beschikbaar zijn, wat vaak resulteert in een 'beter' model dat het nauwer aansluit bij het Vlaams model (dat meestal een goede curvevorm heeft is omdat het gebaseerd is op veel gegevens).

Voorwaarde om goede modellen te bekomen op basis van dit mixed model, is dat er voldoende gegevens beschikbaar zijn. Op basis van ervaring met het gebruik van deze statistische modellen en op basis van eerste testresultaten hebben we volgende voorwaarden voor het basismodel vastgelegd:

- boomsoorten met > 50 metingen per domein in de omtrekklassen tussen 0,5 en 2,3 $\mathrm{m}$ en >= 6 domeinen

- lagere omtrekklassen worden niet meegeteld maar wel meegenomen om het model te fitten (zie Bruikbaar interval/Scope voor omtrekklassen)

\subsubsection{Afgeleid model}

Wat als er niet genoeg metingen zijn om een basismodel te berekenen? Een eerste idee was om 'vergelijkbare' domeinen te clusteren, zodat niet voor elk domein een apart model moest opgesteld worden en modellen van 'vergelijkbare' domeinen zouden kunnen gebruikt worden om hoogtes te schatten voor domeinen met weinig metingen. Maar wat is 'vergelijkbaar', op basis van welke variabele kunnen we de domeinen clusteren? Hiervoor hebben we gezocht naar een correlatie tussen karakteristieken van de opgestelde modellen enerzijds (parameters A, B en C, en hoogteschattingen voor bepaalde omtrekklassen) en potentiële verklarende variabelen anderzijds: bodemtype, ecoregio, provincie ( beheermethode) en ruimtelijke spreiding (getest door resultaten op kaart weer te geven). Er bleek een vaag verband te zijn met bodemtype en ecoregio in de zin dat parameter A en de hoogteschattingen bij (ecoregio's met) rijkere bodemtypen over het algemeen een hogere waarde hebben (wat intuïtief te verwachten was), maar hierbij was nog veel onverklaarbare variatie aanwezig. Zo hadden dicht bij elkaar gelegen bossen soms afwijkende modellen terwijl we hier geen verklaring voor vonden. Dit idee hebben we verlaten bij gebrek aan een duidelijke verklarende variabele voor de variatie tussen de modellen. 
Wat wel een zinvolle methode bleek ingeval van te weinig metingen, is de curve van het Vlaams model (het overkoepelende soortspecifieke model van het basismodel) in hoogte te verschuiven zodat ze terechtkomt in de puntenwolk van de opgemeten punten van het domein. Dit levert het volgende model op:

$$
\begin{aligned}
\text { Hoogte }_{\text {afgeleid }} & \sim \delta A+\text { Hoogte }_{\text {Vlaams }} \\
& =\delta A+A_{\text {Vlaams }}+B_{\text {Vlaams }} \log (\text { Omtrek })+C_{\text {Vlaams }} \log (\text { Omtrek })^{2} \\
& =A_{\text {domein }}+A_{\text {Vlaams }}+B_{\text {Vlaams }} \log (\text { Omtrek })+C_{\text {Vlaams }} \log (\text { Omtrek })^{2}
\end{aligned}
$$

Wat in feite gebeurt, is dat de gemiddelde afstand tussen de meetpunten van het domein en de Vlaamse curve berekend wordt, en dat de Vlaamse curve vertikaal over deze hoogte verschoven wordt. Deze 'verschuiving' is een domeinspecifieke parameter $A_{\text {domein }}$ die corrigeert voor de standplaats (arm/rijk) op basis van effectieve metingen van dat domein; de andere parameters zijn overgenomen uit het Vlaams model. De curvevorm wordt dus overgenomen van het Vlaams model, dat berekend is op basis van een groot aantal gegevens uit verschillende domeinen.

Om een zo goed mogelijk model te bekomen voor de omtrekklassen tussen 0,5 en 2,3 m, wordt het model berekend op basis van enkel de gegevens binnen deze omtrekklassen. Het meenemen van lagere omtrekklassen kan immers als gevolg hebben dat het model een minder goede benadering geeft voor de omtrekklassen boven 0,5 m omdat de lagere omtrekklassen dan ook de gemiddelde afstand beïnvloeden.

Omdat de curvevorm berekend is op basis van het Vlaams model en de domeinspecifieke gegevens enkel nodig zijn om de verschuiving te berekenen, volstaan 10 metingen voor het berekenen van een afgeleid model.

Dus samengevat: de voorwaarden voor een afgeleid model zijn:

- onvoldoende metingen om deel uit te maken van een basismodel

- domeinen met minstens 10 metingen in de omtrekklassen tussen 0,5 en 2,3 m

- lagere omtrekklassen worden niet meegenomen om het model te berekenen

\subsubsection{Lokaal model}

Wat als er voor een boomsoort geen 6 domeinen zijn om een basismodel te berekenen? Als er minder dan 6 domeinen zijn met genoeg gegevens om een basismodel te berekenen (> 50 metingen), dan is de kans groot dat het overkoepelende model (Vlaams model) sterk beïnvloed gaat worden door een of enkele domeinen met veel gegevens en bijgevolg niet representatief gaat zijn voor domeinen over heel Vlaanderen. Dit heeft negatieve gevolgen voor zowel het basismodel zelf (het overkoepelend model gaat de modellen van de domeinen met minder gegevens sterk beïnvloeden) als de afgeleide modellen die hieruit berekend worden (deze worden rechtstreeks afgeleid uit dat minder representatieve Vlaams model).

In geval er van minder dan 6 domeinen voldoende gegevens zijn, is het basismodel onder de vorm van een mixed model bijgevolg niet aangewezen. Voor de domeinen met meer dan 50 metingen, kan echter wel een 'gewoon' lineair model (fixed model zonder random factor) berekend worden op basis van enkel de gegevens van dat domein. Hierbij vallen dan wel de voordelen weg dat het model gecorrigeerd wordt waar er weinig gegevens zijn (zie basismodel) en dat er voor deze boomsoort afgeleide modellen berekend kunnen worden. Dit model, wat we lokaal model noemen, ziet er als volgt uit:

$$
\text { Hoogte lokaal } \sim A_{\text {domein }}+B_{\text {domein }} \log (\text { Omtrek })+C_{\text {domein }} \log (\text { Omtrek })^{2}
$$

De voorwaarden voor dit lokaal model zijn:

- geen basismodel 
- minstens 50 metingen per domein in de omtrekklassen tussen 0,5 en 2,3 m

- lagere omtrekklassen worden meegenomen om het model te berekenen (zie Bruikbaar interval/Scope voor omtrekklassen)

\section{3}

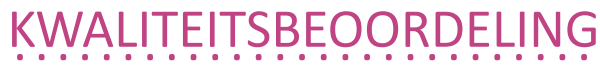

De kwaliteitsbeoordeling of validatie richt zich enerzijds op afwijkende metingen en anderzijds op afwijkende curvevormen. Als error om het betrouwbaarheidsinterval te berekenen met het oog op het selecteren van de afwijkende metingen, gebruiken we de root mean square error (RMSE), die we eerst behandelen.

\subsubsection{RMSE}

RMSE of root mean square error is een maat voor de spreiding van de metingen t.o.v. de opgestelde modelcurve. Deze error is qua principe vergelijkbaar met een standaard error voor individuele gemiddelden (gebaseerd op een som van gekwadrateerde afstanden tussen meting en schatting) en kan dus gebruikt worden om betrouwbaarheidsintervallen te berekenen.

Omgekeerd geeft deze spreidingsmaat informatie over de ligging van de modelcurve ten opzichte van de metingen, waardoor deze waarde ook gebruikt kan worden om modellen te beoordelen of te vergelijken. Zo hebben we voor de keuze van ons model (wiskundige vergelijking, zie keuze van modellen) verschillende modellen opgesteld op basis van dezelfde dataset en op basis van de RMSE de 'beste' modellen geselecteerd (= modellen die de metingen het dichtst benaderen).

We berekenen de RMSE voor het basismodel en het lokaal model door cross-validatie op basis van 6 subsets (dit gebeurt in de functie rmse. basis). Meer specifiek doorlopen we volgende stappen:

- dataset opsplitsen in 6 gelijke delen door de dataset te sorteren volgens boomsoort, domein, omtrekklasse en hoogte en aan de rijen alternerend de nummers 1 tot 6 toe te kennen

- model opstellen op basis van 5 delen

- model toepassen op de records van het 6 de deel, dus de hoogte schatten op basis van de gemeten omtrekklasse en het opgestelde model

- de twee voorgaande stappen $6 x$ herhalen zodat elk record een schatting heeft

- maat voor fit berekenen:

$$
R M S E=\sqrt{\frac{\sum\left(\text { Hoogte }_{\text {gemeten }}-\text { Hoogte }_{\text {geschat }}\right)^{2}}{n-2}}
$$

Voor het afgeleid model, dat een verschuiving van het Vlaams model is, wordt voor de RMSE beide toegepaste modellen in rekening gebracht:

$$
R M S E=\sqrt{R M S E_{\text {Vlaams }}^{2}+R M S E_{\text {Verschuiving }}^{2}}
$$

Hierbij wordt $R M S E_{\text {Vlaams }}$ berekend volgens de hierboven beschreven methode (waarbij de hoogte geschat wordt op basis van het Vlaams model en alle metingen die gebruikt zijn om het basismodel in kwestie op te stellen). Voor $R M S E_{\text {Verschuiving }}$ wordt omwille van het beperkt aantal records voor de boomsoortdomeincombinatie voor elk punt een schatting gemaakt op basis van van een model dat opgesteld is op basis van de dataset zonder dat ene punt, waarna de RMSE op dezelfde manier berekend wordt. (Voor deze laatste berekening is de functie rmse.verschuiving ontwikkeld.) 


\subsubsection{Afwijkende metingen}

We beschouwen een meting als afwijkend als de afwijking van het model groter is dan $2,5 *$ RMSE, dus als de meting buiten het betrouwbaarheidsinterval van de schatting ligt (tussen schatting - 2,5* RMSE en schatting $+2,5 * \mathrm{RMSE})$.

Potentieel probleem? Bij modellen waarbij de RMSE hoog is (bv. hoge spreiding van de metingen of model minder goed aansluitend bij de metingen), zal het betrouwbaarheidsinterval groter zijn, waardoor het risico bestaat dat potentieel afwijkende metingen nog binnen het betrouwbaarheidsinterval vallen en niet als afwijkend aangeduid worden. Om te vermijden om zo potentiële foute metingen te missen (modellen zonder problemen worden niet in de validatierapporten opgenomen), zijn per modeltype (basis/afgeleid/lokaal) voor de 20 domeinen met de hoogste RMSE minstens de 10 metingen met grootste afwijking geselecteerd.

(Deze afwijkende metingen worden berekend in de functie afwi jkendeMetingen die door de functie val idatie. basis, validatie. afgeleid of validatie. lokaal aangeroepen wordt.)

\subsubsection{Afwijkende curvevorm}

Vermits het afgeleid model de vorm overneemt van het Vlaams model (dat in principe een goede curvevorm heeft), wordt een afwijkende curvevorm enkel onderzocht voor het basismodel en het lokaal model. (De selectie van afwijkende curves gebeurt met de functie afwijkendeCurves, enkel de noodzakelijke variabelen berekenen kan met de functie curvekarakteristieken.)

De detectie van afwijkende curvevormen is gebaseerd op het voorkomen van extremen (minima of maxima). Dit zijn de punten waarop de afgeleide van de functie 0 is. Voor ons model treden extremen op bij een omtrek van $e^{\frac{-B}{2 C}}$.

Er kunnen zich 2 situaties voordoen die potentieel afwijkend zijn (beschreven onder Praktische werkwijze/validatie/stap 2: afwijkende curves):

- 'curvevorm hol bij lage omtrekklassen': de hiervoor geselecteerde curves voldoen aan volgende voorwaarden:

- minimum bij omtrek $>0.1 \mathrm{~m}$

- buigpunt ligt boven het begin van het bruikbare interval

- verschil in richtingscoëfficiënt tussen begin van bruikbare interval en buigpunt > 1 (om nagenoeg rechte curves en curves met buigpunt aan het begin van het bruikbaar interval uit de selectie te halen: deze vertonen geen holle curvevorm)

- 'curve daalt terug bij hoge omtrekklassen': de hiervoor geselecteerde curves hebben een maximum binnen het bruikbare interval

(Nota: Een buigpunt doet zich voor waar de tweede afgeleide van de functie 0 is, wat in dit geval is bij een omtrek van $e^{\frac{1-B}{2 C}}$. En een richtingscoëfficiënt (rico) kan berekend worden op basis van de eerste afgeleide, dus voor een welbepaalde omtrek is de rico $\frac{2 C \log (\text { Omtrek })+B}{\text { Omtrek }}$.) 


\subsection{1 outputIVANHO}

De functie outputIVANHO geeft hoogteschattingen voor de 'bruikbare' omtrekklassen, dus de omtrekklassen binnen het bruikbaar interval. Deze tabel kan dus rechtstreeks, zonder verdere berekeningen of randvoorwaarden, geraadpleegd worden om hoogteschattingen op te zoeken of in IVANHO opgenomen worden. Hierdoor wordt ook vermeden dat er rekenfouten optreden doordat het model in dit R-package aangepast wordt maar niet in IVANHO, of omgekeerd.

Voor curves met een maximum binnen het bruikbaar interval, wordt de hoogteschatting gelijkgesteld aan dit maximum voor omtrekklassen boven de omtrekklasse waarin zich dit maximum voordoet.

(Nota: deze functie maakt gebruik van de functies hoogteschatting. basis en hoogteschatting. afgeleid om de hoogtes te berekenen, en van de functie curvekarakteristieken om de maxima in de curves te detecteren.)

\subsection{2 resultaat}

De berekeningswijze van de meeste info uit de tabel die met de functie resultaat gegenereerd wordt, is eerder uitgelegd. De parameters A, B en C worden berekend door de in het modeltype aanwezige Vlaamse en domeinspecifieke parameters op te tellen. Dit betekent:

- voor het basismodel:

- $A=A_{\text {Vlaams }}+A_{\text {domein }}$

- $B=B_{\text {Vlaams }}+B_{\text {domein }}$

- $C=C_{\text {Vlaams }}+C_{\text {domein }}$

- voor het afgeleid model:

- $A=A_{\text {Vlaams }}+A_{\text {domein }}$

- $B=B_{\text {Vlaams }}$

- $C=C_{\text {Vlaams }}$

- voor het lokaal model:

- $A=A_{\text {domein }}$

- $B=B_{\text {domein }}$

- $C=C_{d o m e i n}$

Bijgevolg geldt voor de elk van de modellen in de tabel de algemene functie Hoogte $\sim A+B \log (O m t r e k)+$ $C \log (\text { Omtrek })^{2}$

(Nota: deze parameters kunnen berekend worden met de functie modelparameters.) 
